\title{
Effect of Season, Variety and Phosphorus Fertilization on the Growth and Yield of Groundnut (Arachis hypogaea L.) in Bauchi State Nigeria
}

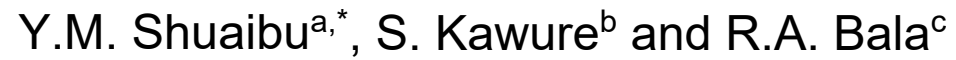 \\ Department of Crop Production, Faculty of Agriculture and Agricultural Technology, Abubakar \\ Tafawa Balewa University Bauchi, Bauchi State, Nigeria
}

aymshuaibu@atbu.edu.ng, bkawure05@yahoo.com, cummuaishat@gmail.com

\section{Keywords: Phosphorous, Season, Variety, Groundnut, Yield}

\begin{abstract}
An experiment was conducted at teaching and research farm of the Abubakar Tafawa Balewa University Bauchi, during the dry and rainy seasons of 2016 to evaluate the effect of variety and phosphorus fertilization on the growth and yield of groundnut (Arachis hypogaea L.). The treatment consisted of two groundnut varieties (Samnut 24 and Samnut 25), two levels of phosphorus fertilizer $(25 \mathrm{~kg}$ and $50 \mathrm{~kg} / \mathrm{ha}$ ) and a control, factorially combined to give six treatment combinations. These treatments were laid out in a randomized complete block design (RCBD) with four replications. Data were collected on the plant height, number of leaves, 100-grain weight and grain yield. All data collected were subjected Analysis of variance (ANOVA) and DMRT was adopted in separating the means. The result of the experiment showed that, there is a significant difference $(\mathrm{P}=0.05)$ in both seasons on all the parameters observed. The results further indicated that, application of $25 \mathrm{~kg} \mathrm{P} / \mathrm{ha}$ produced statistically $(\mathrm{P}=0.05)$ similar result with $50 \mathrm{~kg} \mathrm{P} / \mathrm{ha}$, however the two treatments were better than the control. On varieties, Samnut 25 proved to be significantly $(P=0.05)$ better than Samnut 24 on most of the parameters observed. Based on the result of these findings, application of $25 \mathrm{~kg} \mathrm{P} / \mathrm{ha}$ to Samnut 25 can be adopted by farmers for profitable groundnut production in the study area.
\end{abstract}

\section{Introduction}

Groundnuts (Arachis hypogeae L.) is one of the most important members of the family fabaceae and the sub family Papilionaceae, which originated in the South America (Southern Bolivia/Northwest Argentina region) where it was cultivated as early as 1000BC. The word Arachis hypogaea has been derived from two Greek words, Arachis meaning a legume and hypogaea meaning below ground (referring to the formation of pods in the soil) [1]. Approximately 42 million hectares are grown to groundnut worldwide and producing over 35 million metric tons [2]. Arid and semiarid regions accounted for more than half of the production. China, India, the United States and Nigeria are rated as the major producing countries in the world. Nigeria alone accounted for 3.8 million metric tons out of the total world production of 34.8 million metric tons in 2008 , making about $11.8 \%$ [3]. In Nigeria, it is the most important oil seed crop produced for both export and domestic use. It is distinguished from oil palm by being a non-tree crop cultivated mainly in Northern Nigeria and outside the forest environment of the South. Most of the production is presently concentrated within the semi-arid zone of the country where the mean annual rainfall varies between $800 \mathrm{~mm}$ in the North to $1200 \mathrm{~mm}$ in the south most end of the zone [4]. The leading producing states include Niger, Kano, Jigawa, Zamfara, Kebbi, Sokoto, Katsina, Kaduna, Adamawa, Yobe, Borno, Taraba, Plateau, Nassarawa, Bauchi and Gombe. It is estimated that over 2 million hectares are planted to groundnut in Nigeria [5]. Phosphorus is said to be one of the most essential nutrient element needed by all leguminous plant for their growth and development. However, it has been observed to be a major fertility problems limiting crop production in tropical soil [6]. Farmers however rarely apply phosphorus to leguminous plant because of their believed that groundnut can do without fertilizer and lack of information on appropriate nutritional requirement under Nigerian soil [7]. Because phosphorus is a constituent of nucleic acids and stimulates root growth as well as increase nodules activity in plant, Phosphorus is essentially required for healthy growth with efficient root system and 
profuse nodulation which in turn can affect $\mathrm{N}_{2}$ fixation potential [8]. Recently released varieties (Samnut 24, Samnut 25 and Samnut 26) in Nigeria are resistant/tolerant to most important diseases and are early maturing to escape drought. These varieties are being promoted in the dry savanna region of Nigeria through several initiatives. However, poor agronomic practices such as wide spacing and limited or lack of fertilizer application especially phosphorus reduced the yield of the crop [9]. This study was carried out to determine the best variety and the most effective rate of phosphorus fertilizer on the growth and yield of groundnut in both dry and rainy seasons.

\section{Materials and Methods}

The experiment was conducted at teaching and research farm of the Abubakar Tafawa Balewa University (ATBU), Bauchi. Located at approximately $10^{\circ} 17 \mathrm{~N}, 9^{\circ} 4 \mathrm{E}$ and 609.3 meters above sea level, in the Northern Guinea savanna agro-ecological zone of Nigeria. The materials used were phosphorus fertilizer and two groundnut varieties (Samnut 24 and 25). The treatments consisted of two levels of phosphorus fertilizer ( 25 and $50 \mathrm{~kg} / \mathrm{ha}$ ) and two varieties of Groundnut (Samnut 24 and 25 ) and a control. These were factorially combined to give 6 treatments combinations and laid out in a randomized complete block design (RCBD) with four replications. A plot size of $3 \times 4 \mathrm{~m}$ was adopted, $50 \mathrm{~cm}$ was used as a border row and $1 \mathrm{~m}$ was left as walkway between the replications. Single super phosphate (SSP) was used as a source of phosphorous and the two phosphorus levels were broadcasted and incorporated into different plots during seedbed preparations. The seeds of two groundnut varieties were treated with Apron star and one seed was sown per hole with more than $90 \%$ of the seed emerged 4-5 days after sowing. A composite soil sample of the experimental sites was collected at a depth of $0-30 \mathrm{~cm}$ and used to analyze Physico-chemical properties in the laboratory. Meteorological data were collected during the conduct of the experiment at meteorological station of ATBU, Bauchi. Data were collected on plant height, the number of leaves, 100 -grain weight and grain yield. All data collected were subjected to analysis of variance (ANOVA) and significant differences among the treatment means were separated using the Duncan's multiple Range Test (DMRT).

Appendix 1: Bauchi Meteorological Data, During the Conduct of the Experiment

\begin{tabular}{|l|c|c|c|}
\hline \multicolumn{5}{|c|}{$\mathbf{2 0 1 6}$} \\
\hline MONTH & Rainfall (mm) & Temp. $(\mathbf{} \mathbf{C})$ & RH (\%) \\
\hline January & - & 34.15 & 50.34 \\
\hline February & - & 20.91 & 35.40 \\
\hline March & - & 25.92 & 10.88 \\
\hline April & 39.05 & 29.05 & 34.74 \\
\hline May & 211.36 & 27.51 & 53.60 \\
\hline June & 250.10 & 24.69 & 69.13 \\
\hline July & 154.62 & 24.97 & 82.10 \\
\hline August & 370.45 & 22.13 & 86.75 \\
\hline September & 170.89 & 22.69 & 83.94 \\
\hline October & 40.00 & 23.55 & 64.68 \\
\hline November & - & 29.68 & 39.61 \\
\hline December & - & 19.28 & 27.32 \\
\hline
\end{tabular}

\section{Result and Discussion}

\section{Plant height}

The result revealed a significant $(\mathrm{P}=0.05)$ difference in both seasons on all the parameters observed. The result further indicated that application of $50 \mathrm{~kg} \mathrm{P} /$ ha gave statistically $(\mathrm{P}=0.05)$ similar result with $25 \mathrm{~kg} \mathrm{P} / \mathrm{ha}$, but all the treatments were better than the control. On the other hand, Samnut 25 produced statistically $(\mathrm{P}=0.05)$ taller plants than Samnut 24 throughout the study period. 
The significant difference observed in this study indicated the importance of phosphorous application in promoting plant height of groundnut. The result of this study is in conformity with the result of [10] who reported that application of phosphorous as a single super phosphate (SSP) enhanced crop performance and increase nodule formation for $1878-2403 \mathrm{~kg} / \mathrm{ha}$ as well as biomass production from $2324-2479 \mathrm{~kg} / \mathrm{ha}$. This result further lends support to the findings of [11] who reported that an increase of plant height was recorded from $25.65 \mathrm{~cm}$ to $29.63 \mathrm{~cm}$ due to the application of phosphorus at 40 to $120 \mathrm{~kg}_{2} \mathrm{O}_{5} / \mathrm{ha}$.

Table 1:Effect of variety and phosphorus fertilization on plant height of dry and rainy season groundnut.

\begin{tabular}{|c|c|c|c|c|c|c|}
\hline \multirow[b]{3}{*}{ Treatments } & \multicolumn{5}{|c|}{ Weeks after planting } & \\
\hline & \multicolumn{3}{|c|}{ Dry Season } & \multicolumn{3}{|c|}{ Rainy Season } \\
\hline & 2 & 6 & 10 & 2 & 6 & 10 \\
\hline \multicolumn{7}{|c|}{ Phosphorus (kg/ha) } \\
\hline 0 & $17.70^{\mathrm{b}}$ & $37.80^{\mathrm{b}}$ & $87.73^{\mathrm{b}}$ & $8.13^{\mathrm{c}}$ & $25.43^{\mathrm{b}}$ & $40.97^{\mathrm{b}}$ \\
\hline 25 & $17.66^{\mathrm{b}}$ & $45.60^{b}$ & $106.57^{\mathrm{a}}$ & $9.55^{b}$ & $29.47^{\mathrm{a}}$ & $47.47^{\mathrm{a}}$ \\
\hline 50 & $22.10^{\mathrm{a}}$ & $56.13^{\mathrm{a}}$ & $94.80^{\mathrm{ab}}$ & $11.05^{\mathrm{a}}$ & $29.78^{\mathrm{a}}$ & \\
\hline \multicolumn{7}{|l|}{$45.33^{\mathrm{ab}}$} \\
\hline LS & $* *$ & $* *$ & $* *$ & $* *$ & ** & * \\
\hline $\begin{array}{l}\mathrm{SE} \pm \\
\text { Variety }\end{array}$ & 1.21 & 3.15 & 4.12 & 0.33 & 1.02 & 1.99 \\
\hline $\begin{array}{l}\text { Samnut } 24 \\
43.20^{\mathrm{b}}\end{array}$ & $23.10^{\mathrm{b}}$ & $75.16^{\mathrm{b}}$ & $123.50^{\mathrm{b}}$ & $8.93^{\mathrm{b}}$ & $26.20^{\mathrm{b}}$ & \\
\hline $\begin{array}{l}\text { Samnut } 25 \\
45.99^{\mathrm{a}}\end{array}$ & $29.10^{\mathrm{a}}$ & $81.39^{\mathrm{a}}$ & $138.58^{\mathrm{a}}$ & $10.22^{\mathrm{a}}$ & $29.24^{\mathrm{a}}$ & \\
\hline LS & $* *$ & $*$ & $*$ & $* *$ & * & $*$ \\
\hline $\begin{array}{l}\mathrm{SE} \pm \\
\text { Interaction }\end{array}$ & 1.53 & 2.01 & 4.08 & 0.27 & 0.85 & 0.62 \\
\hline $\mathrm{VxP}$ & NS & NS & NS & $* *$ & NS & NS \\
\hline
\end{tabular}

$\mathrm{LS}=$ level of significant, $\mathrm{SE}=$ Standard Error, NS $=$ not significant, $* * \& *=$ significant at 0.01 and 0.05 probability level respectively, Means followed by same letter within a column are statistically same by DMRT.

Table 2: Interaction of Phosphorus and Variety on plant height of rainfed Groundnut at 2 weeks after planting.

\begin{tabular}{|c|c|c|}
\hline \multirow{2}{*}{ Phosphorus (kg/ha) } & \multicolumn{2}{|c|}{ Variety } \\
\hline & Samnut 24 & Samnut 25 \\
\hline$\overline{0}$ & $7.83^{\mathrm{c}}$ & $8.43^{\mathrm{bc}}$ \\
\hline 25 & $9.60^{\mathrm{b}}$ & $9.50^{\mathrm{b}}$ \\
\hline 50 & $9.37^{b}$ & $12.73^{\mathrm{a}}$ \\
\hline LS & & \\
\hline $\mathrm{SE} \pm$ & & \\
\hline
\end{tabular}

$\mathrm{LS}=$ level of significant, $\mathrm{SE}=$ Standard Error, NS = not significant, $* * \& *=$ significant at 0.01 and 0.05 probability level respectively, Means followed by the same letter within a column are statistically same by DMRT. 


\section{Number of Leaves}

Study on the number of leaves revealed a significant $(\mathrm{P}=0.05)$ difference in both seasons on all the treatments, the result also showed that no significant $(\mathrm{P}=0.05)$ difference was observed between the levels of phosphorous application, but the treatments were better than the control throughout the study period. The variety on the other hand, Samnut 25 proved to be statistically $(\mathrm{P}=0.05)$ better than Samnut 24 in terms of the number of leaves in both the seasons. The significant difference observed in this study indicated the importance of fertilizer application on the performance of groundnut. The variation observed between the varieties could be as a result of better adaptation to the environment by the better variety. The result of this experiment is in conformity with the result of [12] who reported that optimum production of groundnut require balanced nutrition as nutrient deficiencies can have an adverse effect on the groundnut growth, stover and yield components.

Table 3: Effect of variety and phosphorus fertilization on Number of leaves of dry and rainy season groundnut.

\begin{tabular}{|c|c|c|c|c|c|c|}
\hline \multirow[b]{3}{*}{ Treatments } & \multicolumn{5}{|c|}{ Weeks after planting } & \\
\hline & \multicolumn{3}{|c|}{ Dry Season } & \multicolumn{3}{|c|}{ Rainy Season } \\
\hline & 2 & 6 & 10 & 2 & 6 & 10 \\
\hline \multicolumn{7}{|c|}{ Phosphorus (kg/ha) } \\
\hline 0 & $30.53^{b}$ & $147.67^{b}$ & $417.60^{c}$ & $17.40^{\mathrm{b}}$ & $67.73^{\mathrm{b}}$ & $227.43^{b}$ \\
\hline 25 & $37.50^{\mathrm{a}}$ & $165.73^{\mathrm{a}}$ & $450.27^{\mathrm{b}}$ & $19.98^{\mathrm{a}}$ & $91.50^{\mathrm{a}}$ & $238.17^{\mathrm{b}}$ \\
\hline 50 & $38.33^{\mathrm{a}}$ & $168.73^{\mathrm{a}}$ & $475.01^{\mathrm{a}}$ & $21.02^{\mathrm{a}}$ & $89.13^{\mathrm{a}}$ & $255.48^{\mathrm{a}}$ \\
\hline LS & $*$ & $* *$ & $*$ & $* *$ & $* *$ & $*$ \\
\hline $\begin{array}{l}\mathrm{SE} \pm \\
\text { Variety }\end{array}$ & 2.04 & 5.09 & 8.10 & 0.69 & 3.46 & 3.99 \\
\hline Samnut 24 & $43.61^{b}$ & $245.40^{\mathrm{b}}$ & $547.10^{\mathrm{b}}$ & 19.84 & $78.18^{\mathrm{b}}$ & $293.52^{b}$ \\
\hline Samnut 25 & $60.21^{\mathrm{a}}$ & $255.88^{\mathrm{a}}$ & $657.53^{\mathrm{a}}$ & 19.09 & $87.40^{\mathrm{a}}$ & $327.20^{\mathrm{a}}$ \\
\hline LS & $*$ & $* *$ & $*$ & NS & $*$ & $*$ \\
\hline $\begin{array}{l}\mathrm{SE} \pm \\
\text { Interaction }\end{array}$ & 5.21 & 2.46 & 25.50 & 0.56 & 2.82 & 10.96 \\
\hline $\mathrm{VxP}$ & NS & NS & NS & NS & $*$ & NS \\
\hline
\end{tabular}

$\mathrm{LS}=$ level of significant, $\mathrm{SE}=\mathrm{Standard}$ Error, $\mathrm{NS}=$ not significant, ${ }^{* *} \& *=$ significant at 0.01 and 0.05 probability level respectively, Means followed by the same letter within a column are statistically same by DMRT.

Table 4: Interaction of Phosphorus and Variety on number of leaves of rainfed groundnut at 6 weeks after planting.

\begin{tabular}{|c|c|c|}
\hline \multirow{2}{*}{$\begin{array}{l}\text { Phosphorus } \\
\text { (kg/ha) }\end{array}$} & \multicolumn{2}{|c|}{ Variety } \\
\hline & Samnut 24 & Samnut 25 \\
\hline 0 & $70.40^{\mathrm{c}}$ & $63.07^{\mathrm{c}}$ \\
\hline 25 & $77.93^{\mathrm{bc}}$ & $105.07^{\mathrm{a}}$ \\
\hline 50 & $86.07^{\mathrm{b}}$ & $92.20^{\mathrm{ab}}$ \\
\hline LS & \multicolumn{2}{|c|}{$*$} \\
\hline $\mathrm{SE} \pm$ & \multicolumn{2}{|c|}{4.89} \\
\hline
\end{tabular}

$\mathrm{LS}=$ level of significant, $\mathrm{SE}=$ Standard Error, NS $=$ not significant, $* * \& *=$ significant at 0.01 and 0.05 probability level respectively, Means followed by same letter within a column are statistically same by DMRT. 


\section{0 grain weight $(g)$}

The result of this experiment showed that there is a significant $(\mathrm{P}=0.05)$ difference in all the treatments throughout the study period. The result also revealed that application of phosphorous fertilizer at the rate of 25 and $50 \mathrm{~kg} \mathrm{P} /$ ha produced statistically $(\mathrm{P}=0.05)$ similar grain weight but were better than the control. On varieties, however, Samnut 25 was found to be significantly $(\mathrm{P}=0.05)$ better than Samnut 24 in terms of heavier grains. The significant $(\mathrm{P}=0.05)$ difference observed could be as a result of influence of phosphorous fertilizer in promoting root growth which translates to the production of heavier grains. It could also be as a result of variation in the genetic makeup of the two varieties. The result of the present study lends it support to the findings of [13] who reported that application of phosphorous influenced groundnut performance, increased grain filling and final grain weight.

\section{Grain yield (kg/ha)}

The result of this study showed that there exists a statistical $(\mathrm{P}=0.05)$ difference in both the seasons on all the treatments used with regards to yield of groundnut. The result further revealed that application of $50 \mathrm{~kg} \mathrm{P} / \mathrm{ha}$ produced significant $(\mathrm{P}=0.05)$ same result with $25 \mathrm{~kg} \mathrm{P} / \mathrm{ha}$. The study on variety indicated that Samnut 25 was found to be significantly $(\mathrm{P}=0.05)$ better than Samnut 24 in promoting grain yield of groundnut. The significant $(\mathrm{P}=0.05)$ difference observed in this study revealed the importance of phosphorous application to yield of groundnut. The increase in yield due to application of phosphorous is as a result of influence of $\mathrm{P}$ in promoting nodules formation as well as root growth of groundnut. The result of this experiment is inconformity with the result of [14] who reported that the application of 50 and $110 \mathrm{~kg} / \mathrm{ha}$ of phosphorus and calcium respectively has a significant effect on groundnut quality and yield.

Table 5:Effect of variety and phosphorus fertilization on the Weight of 100 pods, harvest index and weight of 100 grain.

\begin{tabular}{|c|c|c|c|c|}
\hline \multirow[b]{3}{*}{ Treatments } & \multicolumn{3}{|c|}{ Parameters } & \\
\hline & \multicolumn{2}{|l|}{ Dry Season } & \multicolumn{2}{|c|}{ Rainy Season } \\
\hline & 100 Grain Weight & Grain Yield & 100 Grain Weight & Grain Yield \\
\hline \multicolumn{5}{|c|}{ Phosphorus (kg/ha) } \\
\hline 0 & $85.73^{\mathrm{c}}$ & $155.58^{\mathrm{b}}$ & $33.93^{b}$ & $417.17^{b}$ \\
\hline 25 & $273.98^{b}$ & $226.66^{\mathrm{a}}$ & $42.27^{\mathrm{a}}$ & $649.67^{\mathrm{a}}$ \\
\hline 50 & $274.33^{\mathrm{a}}$ & $155.83^{b}$ & $40.58 \mathrm{a}$ & $643.83^{\mathrm{a}}$ \\
\hline LS & $* *$ & $* *$ & $* *$ & $* *$ \\
\hline $\mathrm{SE} \pm$ & 16.03 & 31.23 & 1.68 & 34.48 \\
\hline Variety & & & & \\
\hline Samnut 24 & $92.48^{\mathrm{b}}$ & $234.82^{b}$ & $40.88^{\mathrm{b}}$ & $529.33^{b}$ \\
\hline Samnut 25 & $124.41^{\mathrm{a}}$ & $255.22^{\mathrm{a}}$ & $46.98^{\mathrm{a}}$ & $584.44^{\mathrm{a}}$ \\
\hline LS & $*$ & $*$ & * & $*$ \\
\hline $\mathrm{SE} \pm$ & 9.22 & 4.50 & 1.37 & 8.15 \\
\hline Interaction & & & & \\
\hline VxP & NS & NS & NS & NS \\
\hline
\end{tabular}

$\mathrm{LS}=$ level of significant, $\mathrm{SE}=$ Standard Error, NS = not significant, $* * \& *=$ significant at 0.01 and 0.05 probability level respectively, Means followed by the same letter within a column are statistically same by DMRT. 
Table 6: Physico-chemical properties of soil of the experimental sites

\begin{tabular}{lcc}
\hline & Rainy Season & Dry Season \\
\hline Physical analysis & & \\
Sand(\%) & 61.64 & 61.35 \\
Silt $(\%)$ & 21.28 & 22.26 \\
Clay(\%) & 17.08 & 16.39 \\
Texture & Sandy Loam & Sandy Loam \\
Chemical analysis & & \\
Soil pH(water) & 6.36 & 6.53 \\
Organic Carbon $(\mathrm{g} / \mathrm{kg})$ & 7.02 & 7.17 \\
Available $\mathrm{P}(\mathrm{mg} / \mathrm{kg})$ & 5.36 & 6.23 \\
Total N(g/kg) & 0.67 & 0.61 \\
Exchangeable cations $(\mathrm{cmol} / \mathrm{kg})$ & & \\
Ca & 2.52 & 2.36 \\
$\mathrm{Mg}$ & 0.74 & 0.75 \\
$\mathrm{~K}$ & 0.27 & 0.25 \\
$\mathrm{Na}$ & 0.12 & 0.13 \\
\hline
\end{tabular}

\section{Conclusions}

In conclusion, however, phosphorous fertilization plays a significant role in groundnut production in respective of the season. Similarly, Samnut 25 variety performed better than Samnut 24 throughout the study period in both the seasons. Based on the results of these findings, application of phosphorous fertilizer at the rate of $25-50 \mathrm{~kg} / \mathrm{ha}$. to Samnut 25 variety should be adopted by farmers in the study area for both irrigated and rainfed groundnut production.

\section{Conflict of Interest Declaration}

The authors declared that there is no conflict of interest.

\section{References}

[1] A. Singh et al., Influence of planting techniques and plant population on Biology and pod productivity of summer groundnut varieties, Crops Research. 6(1) (2005) 173-174.

[2] H.S.B. Rao et al., Experimental investigation on engine performance of diesel operation on peanut seed oil biodiesel blends, International Journal of Current Engineering and Technology. 3 (2013) 1429-1435.

[3] S. Singh, Phenotypic diversity and identification of wild Arachis accessions with useful agronomic and nutritional traits, Euphytica. 82 (2004) 103-115.

[4] A.B. Garba, M. Auwalu, S.D. Abdul, Effect of Variety and Intra-row Spacing of Flonar Production in Groundnut under the Rrevailing Weather Condition of the Northern Guinea, Nigerian Journal of Agricultural Technology. 9(2) (2002) 102-113

[5] NAERLS. Recommended practices for groundnut production. National Agricultural extension Liason Service, Extension recommended practice. 1 (2010) 5-6.

[6] V.B. Taru, I.Z. Kyagya, S.I. Mshelia, Profitability of Groundnut Production in Michika Local Government Area of Adamawa State, Nigerian Journal of Agricultural Science. 1(1) (2010) 2529.

[7] D.K. Okello, M. Biruma, C.M. Deom, Over view of groundnut research in Uganda, Past, Present and Future African Journal of Biotechnology. 9 (2010) 6448-6459. 
[8] R.D. Kwari, Soil fertility Status in some communities of sourthern Borno. PROSAB, Nigeria. (2005) 21.

[9] A.S. Abdallah, Growth and yield response of groundnut (Arachis hypogaea L.) to microbial and phosphorus fertilizers, Journal of Agriculture, Food and Applied Science. 1 (2013) 78-85.

[10] A.Y. Kamara et al., Phosphorus effects on the growth and yield of groundnut varieties in the tropical savannas of north-east Nigeria, Journal of tropical agriculture. 49(2) (2011) 25-30.

[11] K. Kumar, C.M. Ray, Differential response to groundnuts varieties to phosphorus nutrition in a typical kanhaplohumult, Annual Agricultural Research Journal. 18 (1997) 451-419.

[12] A.S. Fagam et al., Influence of phosphorous levels and intra-row spacing on yield and yield components of groundnut in Bukuru Plateau state, Nigeria, Nigerian Journal of Agricultural and Development Economics. 6(1) (2016) 186-194.

[13] A.S. Fagam et al., Herbage yield of groundnut as affected by phosphorous levels and intra-row spacing in Bukuru Plateau state, Nigeria, Nigerian Journal of Agricultural and Development Economics. 5(2) (2015) 59-66.

[14] K. Razaul et al., Effect of Phosphorus, calcium and Boron on the growth and yield of Groundnut (Arachis hypogea), International Journal of Bio-science and bio-Technology. 5 (2013) 3-7. 